\title{
A History of the State-Media Link in Kashmir
}

\author{
Dilnaz Boga*
}

\begin{abstract}
For decades, the media has been a powerful agency in presenting Kashmir and shaping views in the national and the international imaginations. Recognising the complex multiplexity of the influences on the media that report on Kashmir, this work is an endeavour to examine the history of the media's relationship with the state through Archival Research. Documents accessed from Srinagar's Civil Secretariat's media section of the archives unravel the state's attempts to establish a relationship with the media in the militarised region since the early 1950s. This research sheds light on the nature of the association between the media and the state, as this understanding is crucial in understanding any conflict region. Hence, it becomes necessary to uncover the trajectory of power, as well as the nuances of histopolitical nature of the liaison between the two entities that have contoured the narrative on this region of conflict.
\end{abstract}

Keywords: Kashmir, Media, India, Borderland, State, Censorship, Hegemony, Conflict

\section{Introduction}

This paper delves into archival material to unravel the nature of the relationship between the Indian state and the media from 1950 to 1967, illustrating motives of the state in influencing the source of the narratives that emerged from Kashmir. The state's influence

* Deviprasad Goenka Management College of Media Studies, Mumbai, Maharashtra, India; dilnazb@outlook.com; dilnaz.boga@dgmcms.org.in 
indelibly shaped the reportage of the disputed region while determining how the South Asian borderland was carved into the public's imagination, both on national and international scales (Boga, 2018).

At the onset, the researcher would like to clarify that her work has not scrutinised all the stakeholders of the conflict in Kashmir for logistical reasons, especially in the Pakistani and the Chinese states' motivations in Kashmir. This work centres around records emanating from the Indian state, as this analysis was a part of the $\mathrm{PhD}$ thesis on reportage by the English print media on Kashmir by local (Kashmir Times), national (The Times of India, India Today magazine) and international publications (The New York Times and Time magazine (USA), The Guardian (UK), Dawn (Pakistan)).

\subsection{Background of Kashmir as a Contested Region}

Kashmir lies in the northern borders of India and Pakistan with a population of 70 percent Muslims, and the rest Pandit and Dogra Hindus, Christians, Sikhs and Buddhists (Boga, 2018). Since 1947, the erstwhile state of Jammu and Kashmir has emerged as a contested space between India and Pakistan with wars being fought over it. While India controls three regions: Jammu, Kashmir and Ladakh, it claims the other two regions of Azad Kashmir and Gilgit-Baltistan that Pakistan is administering until the Kashmir dispute is resolved (Boga, 2018; Snedden, 2015). After the 1962 war with India, China has administered the Aksai Chin region of the conflict region (Raghunath, 2006).

The origins of the dispute in the post-Partition phase may be traced back to 26 October 1947, when the Maharaja of Kashmir Hari Singh is said to have allegedly signed the Instrument of Accession in a bid to request India for help in dealing with the tribes that crossed into Kashmir from Pakistan to rescue their family members (Boga, 2018; Rai, 2004). Nonetheless, the much-debated Instrument of Accession is viewed as "provisional pending a plebiscite to determine the will of the Kashmiri people" (Instrument of Accession, 1947). The following day, the Indian armed forces entered Kashmir and the battle turned into the first war, with Pakistan disputing the accession and eventually sending in regular forces (Ali et al., 2011). To this day, the ambiguity surrounding the 
accession has aided India's histo-political narrative, and the occupation of other parts of Kashmir by Pakistan and China has complicated this international dispute, making it the longestrunning conflict at the United Nations (Boga, 2018). Within that frame, Kabir (2009) acquiesces that since then, Kashmir has emerged as a cause of disagreement for three nationalisms - Indian, Pakistani and aspirant Kashmiri. While exploring the notion of a territory of desire in her work, Kabir $(2009$, p. 1) expounds, "To reinscribe desire into the geopolitical claims that (to use phrases in common circulation through India and Pakistan) 'Kashmir is an integral part of India' or, in Pakistan's view, that Kashmir is its 'jugular vein' and its 'unfinished business', is to ask further questions about collective desire." According to the 2011 Census, the Indian side of this undefined frontier is home to 12.5 million (Census, 2011).

On 5 August 2019, with the abrogation of Article 370 of the Indian Constitution that granted the region special status and "autonomy", the statehood of Jammu and Kashmir was unconstitutionally annulled, exacerbating the conflict even further (Dayal, 2020). Visible signs of militarisation are clear in both urban and rural locales of the strife-torn region. Bose (2003) describes Srinagar, Kashmir's summer capital, as a bunker city, symbolising the unabated contours of militarisation.

Over the decades, the conflict has displaced 2,50,000 people, including minority Kashmiri Pandits of Hindu descent (Ali et al., 2011). While structural, direct and indirect violence has been the Indian policy in Kashmir since 1947, human rights violations increased gravely since the 1989 armed uprising and consequently, more than 1,00,000 people have been killed, with over 10,000 enforced disappearances of local men affected by the Indian army (Zia, 2019). To hide the human toll the conflict has exacted on the local population, post-liberalisation, the propaganda machine in India that suppresses political dissent and hegemonises meganarratives for a national and an international audience, operates unhampered, entrenching a militarised solution to a political problem, feeding the burgeoning transnational military-industrialcorporate-state-media complex under the garb of "security", "integration" and "national interest", while solidifying these 
hybrid connections to justify state violence and furthering the state's objective in the world's largest democracy (Boga, 2018).

Historian Mridu Rai (2004, p. 291) summarises the nuances of this location and submits, "Kashmiris have been the subjects of a princely state technically outside the purview of direct colonial interference and also of anti-colonial Indian nationalist appropriation and definition." The state's equation with the Kashmiri population after decades of violence has had varied effects. Encapsulating this relationship, Kabir (2009, p. 151) illuminates why silence is conscripted in the conflict region, "What distinguishes the Kashmiri relationship with the state is the constant knowledge that these invisible forms of power can, at any minute, be displaced by the naked display of an ability to exercise sovereignty, not so much by outright execution or death but by the promulgation and prolongation of uncertain states of being." Particularising uncertain states of being, Fanon (1967, p. 65) expounds that "it is not just an occupation of territory, on the one hand, and independence of persons, on the other - it is the country as a whole, its history, its daily pulsations that are contested, disfigured, in the hope of a final destruction." Under such conditions, "the individual's breathing", he (Fanon, 1967, p. 65) mentions, is "an observed, an occupied breathing - it is a combat breathing". Such colonised spaces of terror breed both, direct and indirect violence, on its inhabitants that is specifically tailored to produce a cultural praxis (Boga, 2018; Mbembe, 2001).

Subsequently, the media, too, in this South Asian borderland's militarised environment operates under heavy strain (Boga, 2018; Joseph, 2000). This paper is, therefore, valuable as it scrutinises the post-independence period when the relationship of the newly formed state and the media took root in the disputed region.

\subsection{Media on Kashmir}

Violation of press freedoms may be a reason India continues to plummet in the global media freedom index. India dropping to the 142 ${ }^{\text {nd }}$ rank out of 180 countries in the World Press Freedom Index 2020 , is testament to how the world's largest democracy is treating its journalists (Reporters Sans Frontiers, 2020). 
In her research, journalist and academic Teresa Joseph (2000) posits that issues perceived to have a bearing on national interest or security, particularly those relating to defence, foreign policy, insurgency and human rights, are usually portrayed from a statesecurity perspective, relegating the priorities and concerns of the people to invisibility, and the Indian press is no exception to this practice, with the absence of coverage of the human rights situation in Kashmir as an explicit case in point (Boga, 2018). Exploring another dimension, Chindu Sreedharan's (2009) work reveals that international media have, at times, leaned on the national media and official versions to highlight issues projected by the usual suspects that are fed to parachute journalists by state and non-state actors.

Targeting journalists is common in Kashmir. In the 1990s, after expelling all foreign journalists from Kashmir, the state arrested 57 local journalists in June 1991 (Mughees-Uddin, 1992). Recently, photojournalist Masrat Zahra was also booked under the Unlawful Activities Prevention Act by the Jammu Kashmir Police for "uploading anti-national" posts on social media (Free Press Journal, 2020). Similarly, The Hindu's correspondent Peerzada Ashiq was summoned by the police over a story he published on tensions between Kashmiris and the police (Committee to Protect Journalists, 2020). Monitoring press freedoms in Kashmir, media watchdog Reporters Sans Frontieres comments, "Finally, coverage of regions that the authorities regard as sensitive, such as Kashmir, continues to be very difficult. Foreign reporters are barred from Kashmir and the Internet is often disconnected there" (Press Trust of India, 2019). For these reasons, this veiled space of conflict needs further exploration.

\subsection{Media Landscape in Kashmir: Pre-1947 Phase}

In 1904, Maharaja Pratap Singh not only declined permission to Munshi Muhammad Din Fauq to start a newspaper from Srinagar but also framed rules that would disallow even consideration of such requests, and so for 30 years newspapers were not produced in the Valley (Ahmad, 2016). By 1931, the Valley's last rulers, the Dogras, had been trying to stifle a mass movement for equality launched by Kashmiris. Some Lahore newspapers took up the 
cause of the disempowered Kashmiris (Rai, 2004). Due to the criticism of anti-Muslim state policies, some periodicals were banned, although some copies would reach Srinagar clandestinely (Ahmad, 2016). Since the establishment of the local press in 1932 by Kashmiri journalist and freedom fighter Pandit Prem Nath Bazaz, the nature of the local media transformed from being a hearth for innovative ideas and reforms for the establishment of a new nation to being reduced to produce selective reportage events after 1947 (Ghosh, 2017; Boga, 2019).

Documents reveal that post-independence, the autonomy of the press was limited and even poems that appeared in the newspapers were scrutinised by the establishment. For example, a letter, by the law department to the principal information officer, complained about an Urdu poem titled Ab Kashmir Ka (Now of Kashmir) by one Munshi Biyabani that was published in the weekly paper, Kashmir Mail Jammu (Information Department, 1951). The poem was examined as the writer had used words such as zulam (tyranny), sitam (oppression) and Muzalman (Muslim) (Information Department, 1951). In the same letter, another poem, In Kashmir by the same writer outlined the tyrannies perpetrated in Kashmir by government officers. Adding a political dimension to the official response to the poem, the letter cautions: "To take action against such an ordinary paper is to bring it in the lime-light and give undue publicity to it which it hardly deserves. Besides, in view of the coming elections perhaps it will not be expedient to take any action at this time" (Information Department, 1951).

Although Kashmiri Pandits constituted a microscopic minority, their influence was widespread due to their close relationship with the ruling elite, and during different periods of history, they were used as "instruments of tyranny" by various regimes that ruled over Kashmiris (Abdullah, 1986, p. 170). Over centuries, the politics of identity has been deeply imbricated with the everyday operations of statecraft in Kashmir (Bhan, 2016). Journalism, too, remained a monopoly of those with access to education till 1990 the higher class and caste - the Brahmins or the Kashmiri Pandits, so much so that only Pandits worked as journalists and editors representing Kashmir nationally, internationally and as official media in Srinagar (Ahmad, 2016). Consequently, Rasool (2020: 
online) concurs: “Kashmir's story, ravaged from misreporting and state-sponsored journalism in the past more than three decades has been pushed to an extreme, with hardly any representation in media to the local populace to speak for themselves and question the narratives crafted in the studios, thousands of miles away."

\subsection{Motives of a New State}

Historical evidence in the form of archival documents of the Press Information Bureau and the Information and Broadcasting Ministry (I\&B Ministry) of the Government of India from the 1950s onwards not only unravels how the new neo-colonial state perceived media but also reveals its intentions to prevail upon the Fourth Estate.

An analysis of a gamut of documents exhibits how the state, a visible manifestation of power, attempts to weaponise the local media, transforming it into a producer of government press releases by diluting press laws, and systematically inculcating an unhealthy dependence on advertisements from various arms of the state. The evidence laid out in the following sections reveals that the transition of the media was accompanied by concerted efforts by the state to first legitimise, institutionalise, and then incentivise, through loans and advertisements, into producing news on "development", rather than depict Kashmir's traumatised reality. The state's motive to influence what the media produces unveils its covert motivations and agendas. For example, a complaint letter to the Director-General of Information Department J. N. Zutshi from an employee Mohammed Yusuf from the Information and Broadcasting Ministry about irregularities in the CounterPropaganda Department in the Press Information Bureau of the J \& $\mathrm{K}^{\prime}$ s Information and Broadcasting Ministry, confirms the existence of this department in 1950 (Press Information Bureau, 1950). This suggests that during that period, the state's motive was to manage the information that was disseminated to the public on Kashmir to protect its interests at national and international levels. This exercise by the state is resorted to when the rest of the population is required to comply with power (Chomsky, 1991).

Manufacturing, managing and disseminating information are functions of hegemonic power. As the dispute on Kashmir was on- 
going, the state sought to imprint its position through the media by disseminating information that supported its claims on the contested region. Over time, mechanisms to influence public opinion through the media may be used to "integrate" a region within a dominion and also frame the local resistance as hostile to enable it to justify violence (Boga, 2019). Contextually, both public and elite political agendas are likely to be influenced by decisions about which events, programs and ideas receive coverage and the perspective used in the media coverage (Reddy, 2006). Power of propaganda lies in its ability to mobilise a consensus, to give the appearance of democratic consent and to create enough confusion, misunderstanding and apathy in the general population to allow programs instituted by the ruling elite to flourish (Barsamian, 2001). Contrary to what the name of the department discussed above suggests, evidence in the next section indicates its primary function was spreading state propaganda.

A letter from the Information Department (1954) informs about the screening of "propaganda films in villages" and a "request to send police in advance to maintain law and order" as "mysterious persons shouted anti-government slogans and a minor skirmish took place". Firstly, this information indicates that a pro-freedom sentiment existed in the Valley. Secondly, the letter confirms that the state was attempting to "integrate" Kashmir into India by altering the will of the Kashmiris through exposure to propaganda films in far-flung villages. Lastly, it exposes how power counters people's legitimate political aspirations. Weaponisation of cultural creations such as films within hegemonic statist frames enables power to set its agenda to manage mass opinion. For exerting its power to alter the public narrative in the Valley through film, one may argue that media is a secondary power-wielding mechanism within state structure (Castells, 2009).

\subsubsection{State-Induced Dependence of the Media}

To examine the nature of the dependence of the state on the media, and to highlight the contradistinction in the state's perception between the objectives of the local and the national media, a different dimension to the discourse on the state-media link is presented (Information Department, 1966): 
"For press publicity in the State, we have to depend on local newspapers. The larger the circulation of a newspaper, the greater the publicity that can be achieved through it. In the absence of a newspaper with an appreciable circulation, we have to depend on press publicity entirely on newspapers published from Delhi."

The modus operandi of the state's press publicity and its need for a high circulation for propagating its views, thereby minimising or diluting opposition from diverse voices, emerges from this letter. This makes the state's requirements visible, emphasising the need to dominate any newspaper space available, locally or nationally and its goal of setting agendas. As there is no trace of media's resistance in the letter, one may infer that the relationship between the state and the media was a symbiotic one, especially because the letter states that national newspapers in Delhi had provided publicity space to the state (Information Department, 1966). Hence, one may contend that the national media was not independent and propaganda-free and that it had already been compromised in the 1960s.

Moreover, the same letter discloses that it was in the state's interest to have local newspapers with higher circulation to be able to exploit their reach (Information Department, 1966). The interventionist state played a crucial role in weakening the primary function of "democratic" media by strategically cultivating a dependence on it, seeking to control it to use it for opinion-building with propaganda, protecting its structure and marginalising identities at a large scale. Colonial tactics regulated the media in the new "democracy", thereby eroding it since its inception.

Despite the policy of the Government of India to not grant loans to any local newspaper established as a commercial venture, and for precisely the purpose of exerting control and ensuring a publication's "healthy circulation", interest-free industrial loans up to rupees one lakh were granted by the state government to newspapers (Information Department, 1966). To first legitimise unethical arrangements and then systematise them, the Enquiry Committee on Small Newspapers, in the letter, recommends that financial 
assistance "in some form or the other", be awarded to small newspapers through state governments in consultation with the Union Ministry of Industry (Information Department, 1966).

In a follow-up, to stem dissent against this move, and regulate this illegitimate alliance, the Enquiry Committee categorised newspapers as "an industry like any other industry and therefore should be eligible even for industrial loans", turning the printing presses into government property (Information Department, 1966). This mutually beneficial, accommodative measure laid the foundation for a strategic interdependence between the state and the media by legitimising an unethical and inappropriate relationship, compromising the Fourth Estate. Specifying the outcome of this co-optation, the Information Department's (1966) letter confirms that the photographs released by the department were being carried in national publications such as Hindustan Times, Times of India, Indian Express, The Patriot, etc. These steps mark the beginning of the state's influence and effect on the media and the specific nature of its relationship. Relating this form of cooptation, coercion and control to Foucault's (1991) concept of governmentality, which covers social management processes and practices, including the distribution of discourses of public authority, one may conclude that the state in Kashmir asserts its authority through the exercise of power.

Simultaneously, draconian measures prevented the media from being a central component of a vibrant public sphere. A letter from the Director Information to the Chief Secretary Srinagar (Education and Health) about granting permission for printing newspapers and the conditions sanctioned by the punitive state illuminates its motivations to gag narratives in the name of public security (Information Department, 1954a):

"There should be no mushroom growth of such newspapers which seek to bring the Government into disrepute through scurrilous writings or otherwise threaten public order and public security in the state. Conditions prevailing in the state are very different from other parts of India. Security deposit of 
Rs. 1,000 forfeited if paper indulges in objectionable writing as per Section 15(A) of the Public Security Act."

Critiquing state policies is an essential component of the media, which develops people's trust and nation-building within a democratic set-up. The takeover of the printing press increased the publishers' economic dependency on the state, leaving no room for alternative political views, debates, questions or arguments. Regulation of political thought processes and public discourse at multiple levels was achieved through this exercise.

\subsubsection{Weaponising Local and National Media}

A letter on 11 November 1964, to Chief Secretary Jammu and Kashmir E. Mangat Rai, from L. R. Nair, Principal Information Officer, Press Information Bureau, New Delhi, shows the establishment's perception about the national media and the reason to control it in Kashmir (Press Information Bureau, 1964). The letter contained clippings of articles from newspapers that represented local political parties, with instructions to deal with the material through various measures (Press Information Bureau, 1964). Certain words of the letter have been italicised by the researcher for emphasis as they divulge the motive of colouring Kashmir's portrayal from a statist perspective.

"Perhaps some positive results could be achieved by establishing contacts with these papers at public relations level. Simultaneously, the nationalist press in the state may also be encouraged to write more frequently with conviction and vigour in support of the Indian stand on Kashmir. We can even afford to be repetitive. A large flow of publicity material on development projects in the state will also be helpful in countering the negative policy of anti-India forces there. The PIB will be willing to supplement the efforts of the Directorate of Information on all-India scale."

In a certain light, media's function may be reduced to that of an instrument employed by regimes to reproduce the values and structures that help maintain a hierarchy, enabling the consolidation and expansion of power to exert control over the population. On the utility and expansion of such power, Mbembe (2001, p. 30) finds "a connection between socio-political arrangements and the culture of power developed in the conquered 
territories". This meticulously tailored reconstruction of reality through power and culture is exalted to a repetitive spectacle for the population where it is re-presented in a different form that does not challenge the establishment but further expands its hegemony. Hence, one may argue that a conflict's interpretation and portrayal in the media may be contingent on one's political location and victimology. Citing another example, a letter from journalist B. K. Tufchi to Health and Education Minister of Jammu and Kashmir G. $N$. Sadiq clarifies "enlarging the scope and extent of our cooperation" (Information Department, 1955). Tufchi writes: "I may assure you that as in the past, I will not fail to do my bit consistently with the principles and demands of my own professional duties, in helping the cause of the State. As suggested by you, I am looking forward to meeting you when it will be possible for me to place any suggestions that I may have before you" (Information Department, 1955). Such non-confrontational and symbiotic relationships with the state took many configurations.

One such configuration can be traced to documents about the minutes of a meeting of various officials on media coverage and through letters sent to journalists/editors by officials of the Information Department which uncover motivations of the two centres of power - the State/the Centre and the media. A letter by the Director of Information of the Government of Jammu and Kashmir encapsulates the state's perception of newspapers and how the Information Department manoeuvred to exploit the media to its advantage, reflecting the nuances through which the state viewed the national and the local media and the need to "encourage" them (Information Department, 1966):

"The publication of a story in a national newspaper has its own importance because of the special type of readership that the paper commands. Therefore, our effort has been and will always continue to be to get maximum space in the national dailies. However, at the same time, measures will have to be adopted to build up other means of press publicity. My concerned opinion is that we must build up some of the local newspapers that have the requisite potentiality that we are able to reach the maximum people particularly the intelligentsia in the State. If the news- 
service, the get-up, the general reading matter of a newspaper improve, its circulation is bound to increase."

The state patronises dailies by "building up" means of publicity because of the "special type of readership" which translates into the targeting of the local elite, which is an essential component in opinion-building. The authorities not only aim to exploit the amount of space in the national and local media but also reach a maximum audience with its version of reality. Entman (2007) posits throughout history, the control of socialised communication by ideological and political authorities and the elite has been a key source of social power. Replacement or omission of people's narrative with statist versions not only produces a simulated version of the region, but also explicitly affirms the state's will to first build, and then, exploit the media through various means, turning it into a weapon. The media not only carves identities to promote hegemonic agendas but also redefines the nature and purpose of groups that oppose the state. Resultantly, such covert misappropriation by power ends up achieving a refeudalisation of sorts under a post-capitalist democracy and misrepresents Kashmir's reality to India and the world (Boga, 2019). Gramsci (1975) deconstructs such state practices by explaining that unitarian fanaticism produces a permanent atmosphere of suspicion towards anything that might smack of separatism and that violence and denial of justice by the repressive state systematically erodes the social fabric of the society, creating unending cycles violence, impunity and a reactionary violent resistance.

For example, The Mirror Weekly carries an article written by Prime Minister of Jammu and Kashmir Gulam Mohammad Bakshi (1962): "Rapid economic development is the key to the solution of all problems, political and social, confronting the people of Jammu and Kashmir. ... some people loosely talk of 'special status' that Jammu and Kashmir is supposed to enjoy. In effect no such special status, as alleged, exists after all the measures that have been taken for bringing about closer integration of this state with the Indian Union." This thematic hyperisation of "integration" is prevalent in the media even in present times (Saikumar, 2019; Duckduckgo, 2020). 
In a similar vein, in an overt bid to recruit collaborators, another letter from the Minister of Information G. N. Sadiq to ten editors and correspondents exposes the outcome of the co-optation and the symbiotic relationship shared between the media elite and the state at various levels (Press Information Bureau, 1964a):

"We are aware of the usefulness of close contact between the Press and the Government. We are conscious of the help and cooperation we have been receiving from you at all stages."

Such type of manipulation is precisely what Bernays (1928) terms 'regimentation of people's minds', which is a central concept of propaganda. Naturally, such control on information requires close monitoring of all publications. The state maintained an extensive list of critics of state practices and policies in each publication, both local and foreign (Press Information Bureau, 1965). Despite such scrutiny and interference, sections of the local press that resisted the pressure continued to perform.

Over the years, in some cases of censorship, local publications in Kashmir were banned for a few months if they challenged or exposed the state or failed to comply and report on subjects or material that it provided them with. The authorities would prevent the entry of undesirable publications and newspapers into the state from outside. A history of the state banning publications that critique their policies is confirmed not only through the official proof from the archival material but is evident to this day (Agarwal, 2018). Examples below verify these claims.

In 1967, after encountering an analysis of critical editorial content in local publications such as Kashmir Times and Ujala about "leaders being thrust upon people"; and another one in the "foreign press round up" on 11 December 1967, weekly newspaper Our Country was prohibited from publication for three months by Government of Jammu \& Kashmir under Chief Minister G. N. Sadiq for "securing maintenance of public order", under 46 (1)b Defence of India Rules, 1962 (Information Department, 1967). Any form of critique of state policies was reprimanded under the unquestionable garb of securitisation and nationalism, thereby setting the framework for the future. For example, local newspaper 
Kashmir Reader was banned by the state on 2 October 2016 (Scroll, 2019).

\subsubsection{State, Army and Media Nexus}

Furthermore, files labelled "confidential" from the Government of Jammu \& Kashmir, Civil Secretariat's Information Branch, about the minutes of a meeting between Commissioner, Kashmir, Officer on Special Duty Information and Broadcast, Government Of India, Secretary to Government, Home Department, Deputy Principal Information Officer, Government Of India, Station Director, Radio Kashmir, Director Information, Srinagar, Public Relations Officer, Armed Forces, Secretary to Government, Information Department and one major A. S. Agnihotri of the Indian Army, expose another level of collaboration, revealing the link between the state, the media and the army in Kashmir (Information Department, 1964).

Documents disclose what the state conceals from the public and what it wants the local media to circulate or hyperise to the level of a spectacle for the benefit of the national and international media. The practice of doing background checks on foreign media personnel had been established to "drown out any unfavourable coverage by the press", thereby keeping the public in the dark about vital facets of the conflict that shape their perception (Information Department, 1964). An excerpt from the letter shows the scrutiny that entailed the "management" of foreign reporters (Information Department, 1964):

"The Director External Publicity will be requested to give the background of the visiting foreign journalists... The Director of Information will obtain from the Deputy Principal Information Officer the background material about visiting foreign journalists... to eliminate the possibility of 'Leakages'."

This instance presents as another dimension to the layers of collaboration and informs how the international media was fed material generated by the state to propagate a certain projection of Kashmir and highlight irrelevancy to distract the public from the core issue that affected them. Under the section "Administrative Policies", the participants of the meeting reiterate (Information Department, 1964): 
"Policies of the state government should be highlighted even at the risk of repetition with a view to bring out change in the situation resulting from the State Government's desire to normalise conditions. Stress should invariably be laid on the fact that enjoyment of these liberties is possible only in our country."

Methods of constructing, institutionalising, mainstreaming and organising propaganda had been employed by the state for the international, national and local media in Kashmir at an early stage of the dispute when the people were demanding their universal right to self-determination. The state's desire to "normalise" conditions arose from its will to "bring about change in the situation" (Information Department, 1964). This not only reflects the state's realistic and grassroot-level understanding of the public's political demands of self-determination but also exposes its attempt at "normalising" the portrayal of the people's uprising to those outside Kashmir. Notably, Kashmir's misrepresentation through the media largely taints the public's understanding of the conflict, making it one of the most shrouded regions in the world.

To uncover the link between how these standardised practices permeate what the media produces, the researcher would like to elaborate on the minutes of the same meeting (Information Department, 1964):

"The Commissioner (Information), Kashmir stressed the need for stepping up publicity regarding developmental activities in the State so that the impression regarding normal conditions in the State is reinforced in public mind."

"Peaceful conditions and normalcy in the Valley are to be emphasised to dispel apprehension about the convenience of tourists."

Artificial assemblages of "development", "normalcy" and "tourism" are the three main intersectional discourses that the national media weaves, independently or in combination, into the mega-narrative on the conflict. The fictitious link between the three constructs cited above translates into a version of reality for a majority of the public outside the Valley. Till date, the state's concocted mega-narrative functions to replace the people's narrative and is often hyperised to a repetitive spectacle and a "false reality" in times of mass uprisings that are difficult to conceal 
because of social media and explain, domestically and globally (Kannabiran et al., 2020).

These synthetic constructs were concocted and methodically propagandised by the state through the media as early as the 1960s, consolidating the falsifications for generations. Theorists argue that power produces overarching narratives and one is not permitted to depart from or publicly challenge them. "The champions of state power invent entire constellations of ideas; they adopt a distinct set of cultural repertoires and powerfully evocative concepts but they also resort, if necessary, to the systematic application of pain. The basic goal is not just to bring a specific political consciousness into being, but to make it effective" (Mbembe, 2001, p. 103). Foregrounding the confluence of motives highlighted above, one may posit that such manoeuvrings by the hegemons are conceived and implemented to consolidate and then, expand the power and alter political consciousness en mass.

Over time, propagandisation of these synthetic narratives through intersectional assemblages into the public realm through the media and the circuitous and repetitive nature of the message illustrates how the state weaponised the media when the need arose to derail and misrepresent the organic narrative of self-determination from the people that emerged from the Valley.

\subsection{Conclusion}

Media are the means by which conflicts are played out. Archival evidence unravels the imbalance in power and the influence of the state on the Fourth Estate after India's independence in 1947. Uncovering the historical relationship of the state to the local and the national media enhances our understanding of the effects of the state's manipulation of various levels of media, as early as the 1950s. There were those that the state could manipulate and co-opt, but there were those who endured the brunt of the state's hegemonic functioning.

Documents confirm how the state strategises ways to weaponise or subjugate the media to portray a hegemonic narrative on the region of conflict. Evidence has been presented to enhance our understanding of how power functions, consolidates and controls 
variables that seek to present an alternative view of reality. Minutes of meetings between officials on media coverage show how the state patronises coverage of events in dailies as its involvement in manufacturing consent, targeting the intelligentsia, producing a simulated version of the region.

The state also monitored and maintained a list of critics of policies in local and foreign publications. Documents also disclose what the state conceals from the public and what it highlights in the national and foreign press to drown out any unfavourable coverage to control public perception. Such techniques of constructing, institutionalising, mainstreaming and organising propaganda have been practised in Kashmir since the 1950s. Through such Machiavellian techniques the hybrid assemblages of "development", "normalcy", "peace", "terrorism" and "tourism", which feature prominently presently, came into being. Examples cited above expose the beginning of the state's control on the media covering Kashmir.

\section{References}

Abdullah, M. S. (1986). Flames of the Chinar. New Delhi: Penguin Books India.

Agarwal, K. (2018, May 3). How Free is the Media in the Kashmir Valley? The Wire URL https://thewire.in/media/how-free-is-the-media-inthe-kashmir-valley Retrieved 19-04-2020.

Ahmad, K. (2016, 23 August). Kashmir's Media experience continuum. Kashmir Reader URL http://www.kashmirreader.com/ 2016/08/23/ kashmirs-media-experience- continuum/?amp_markup=1 Retrieved on 11-5-2018.

Ali, T., Bhatt, H., Chatterjee, A., Khatun, H., Mishra, P \& Roy, A. (2011). Kashmir: The Case for Freedom. London: Verso.

Bakshi, G. (1962, 18 August). Let Article 370 be scrapped for all I care. The Mirror Weekly. "Rapid economic development is the key to the solution of all problems, political and social, confronting the people of Jammu and Kashmir." ... "The State Prime Minister declared: some people loosely talk of "special status" that Jammu and Kashmir is supposed to enjoy. In effect no such special status, as alleged, exists after all the measures that have been taken for bringing about closer integration of this state with the Indian Union."

Barsamian, D. (2001). Propaganda and the Public Mind - Conversations with Noam Chomsky. New Delhi: Madhaym Books. 
Bernays, E. (1928). Propaganda. Historyisaweapon.com URL http:// www.historyisaweapon.com/defcon1/bernprop.html Retrieved: 12-12018

Bhan, M. (2016, April 2). Divide and rule. Kindle. URL http:// kindlemag.in/divide-and-rule/ Retrieved: 2-5-2020

Bose, S. (2003). Kashmir: Roots of Conflict, Paths to Peace. Cambridge: Harvard University Press.

Boga, D. (2018). PhD thesis titled 'Locating Kashmir in Mainstream Print Media: A Multi-level Inquiry from 1990 to 2010', submitted in the fulfilment of the requirements for the degree of Doctor of Philosophy in Development Studies at the School of Development Studies, Tata Institute of Social Sciences (Mumbai) in October 2018. URL https://sg.inflibnet.ac.in/handle/10603/257569 Retrieved 21-04-2020.

Castells, M. (2009). Communication Power. New York: Oxford University Press.

Census (2011). Jammu and Kashmir Population 2011-2020 Census URL https://www.census2011.co.in/census/state/jammu+and+kashmir.h tml Retrieved 19-04-2020.

Chomsky, N. (1991). Media Control: The Spectacular Achievements of Propaganda. New York: Seven Stories Press.

Committee to Protect Journalists (2020, 20 April). Jammu and Kashmir police launch investigations into 2 journalists. Committee to Protect Journalists. URL https:/ / cpj.org/2020/04/jammu-and-kashmir-policelaunch-investigations-int.php Retrieved 21-04-2020.

Dayal, S. (2020, 19 January). Open Wounds. Caravan magazine. URL https://caravanmagazine.in/conflict/resist-to-exist-four-openwounds Retrieved 19-04-2020.

Duckduckgo. (2020). Integration of Jammu and Kashmir. URL https:/ / duckduckgo.com/?q=integration+of+jammu+and+kashmir+ $\& a t b=v 218-2 \& i a=$ web Retrieved 08-05-2020.

Duschinski, H. (2009). Destiny Effects: Militarisation, State Power, and Punitive Containment in Kashmir Valley. Anthropological Quarterly, 82(3).

Entman, R. M. (2007). Framing bias: Media in the distribution of power. Journal of Communication, 57(1), 163-173.

Fanon, F. (1967). Black Skin, White Masks. The Experiences of a Black Man in a White World. New York: Grove Press.

Foucault, M. (1991). Governmentality. In The Foucault Effect: Studies in Governmentality. ed. G Burchell, C Gordon, P Miller, pp. 87-104. Univ. Chicago Press: Chicago.

Free Press Journal. (2020, April 20). Who is Kashmiri journalist Masrat Zahra? Why was she booked under UAPA? Free Press Journal. URL 
https://www.freepressjournal.in/india/who-is-kashmiri-journalistmasrat-zahra-why-was-she-booked-under-uapa Retrieved 21-04-2020. Ghosh, P. (2017, July 16). Pandit Prem Nath Bazaz - a misunderstood and revolutionary Kashmiri Pandit. Hindustan Times. URL https:// www.hindustantimes.com/india- news/pandit-prem-nath-bazaz-amisunderstood-and-revolutionary-kashmiri-pandit/storyMXcRZoUTA3kcJcf3pseGTK.html Retrieved: 12-5-2018.

Gramsci, A. (1975). Prison Notebooks Volume I. New York: Columbia University Press.

Information Department. (1951, August 28). Letter No: 202/B/51. To The Principal Information Officer, J\&K Govt., Srinagar, Reference to your no: IBC/3213/51, dated 18-8-1951 by Law Secretary. The long Urdu poem titled by Munshi Biyabani Ab Kashmir Ka (Now of Kashmir), abolished in weekly paper Kashmir Mail Jammu of 10th August 1951 has been examined in this department. The writer has used words such as zulam, sitam, Muzalman in this poem. Another poem called In Kashmir by the same writer about which opinion was expressed by the law department vide U.O no: 202-B/51, dated 16.8.51... It is not a fit case for taking action under the Press \& Publications Act. Apart from the legal view stated above, it may be pointed out that the paper Kashmir Mail Jammu, in which the poem is published is a very ordinary paper and its circulation is very limited. To take action against such an ordinary paper is to bring it in the lime-light and give undue publicity to it which it hardly deserves. Besides, in view of the coming elections perhaps it will not be expedient to take any action at this time. English reading of some of the verses of the poem is given as follows: "The tyrannies that are being perpetrated in Kashmir by responsive officers outdo even Satanic misdeeds. There has grown a settled tendency on the part of these responsible officers to harass individuals... The cruelties perpetrated on the people are described to be "of a shocking character". Crime is alleged to flourish 'unchecked' as a consequence of offenders being 'let off' without punishment. The last stanza also makes a reference to the inhuman cruelties resorted to by officers of Government. The officers are described to be "beasts of prey continuing their depredation when life is almost extinct in their victims". Retrieved from the archives in April 2015.

Information Department. (1954, June 10). Letter No 619/C. From the Superintendent of Police Anantnag to Director Information and Broadcasting about the display of propaganda films in villages and request to send police in advance to maintain law and order. Mysterious persons shouted anti-government slogans and a minor skirmish took place. Retrieved from the archives in April 2015. 
Information Department. (1954a, July 12). Letter No IB/3970-72/54. To Chief Secretary Srinagar, Education and Health, from Director Information for granting of permission for printing newspapers. There should be no mushroom growth of such newspapers which seek to bring the Government into disrepute through scurrilous writings or otherwise threaten public order and public security in the state. Conditions prevailing in the state are very different from other parts of India. Security deposit of Rs. 1,000 forfeited if paper indulges in objectionable writing as per Section 15(A) of the Public Security Act. Retrieved from the archives in April 2015.

Information Department. (1955, May 12). Letter No: 3381/0/55. To G. N. Sadiq, Health \& Education Minister, J \& K Government from B K Tufchi, Press Correspondent, Srinagar. The letter suggested "enlarging the scope and extent of our cooperation". "I may assure you that as in the past, I will not fail to do my bit consistently with the principles and demands of my own professional duties, in helping the cause of the State. As suggested by you, I am looking forward to meeting you when it will be possible for me to place any suggestions that I may have before you." Retrieved from the archives in April 2015.

Information Department. (1964, June 13). File no 10 72/66 GO MS No 1089. Confidential Report. Minutes of a meeting on the state's Administrative Policies of the media between Commissioner, Kashmir, Officer on Special Duty Information and Broadcast, Government Of India, Secretary to Government, Home Department, Deputy Principal Information Officer, Government Of India, Station Director, Radio Kashmir, Director Information, Srinagar, Public Relations officer, Armed Forces, Secretary to Government, Information Department and major A. S. Agnihotri of the Indian Army. The state aimed to conceal from the public and what it wanted the local media to circulate to the level of a spectacle for the national and foreign press. This practice had been instituted to drown out any unfavourable coverage by the press, thereby keeping the public in the dark about vital facets of the conflict that shape their perception. An excerpt from the letter shows the scrutiny that entailed the "management" of foreign reporters. Concepts on propagation of peace, normalcy, tourism and development discussed with regards to media. Retrieved from the archives in April 2015.

Information Department. (1966, May 21). File no 10 72/66 GO MS No 1089. Notification from Deputy Secretary A R Gopalan of the Home Department, Jammu and Kashmir government to Government and to Director of Government Printing Andhra Pradesh Hyderabad, Railway Deputy Inspector General, Superintendent of Police Special 
Branch, Crime Investigation Department (CID) Hyderabad, Director of Posts and Telegraphs, Registrar of Andhra University, all Collectors and Osmania University, Hyderabad on banning maps showing Jammu and Kashmir and Tripura as excluded from India that were printed in exercise books by Shekhar Litho Press in Andhra Pradesh . Retrieved from the archives in April 2015.

Information Department. (1966, August 31). File no 10 72/66. In reference to letter no ID 80/66 dated 10/8/66 Prohibition of publication, the state banned the sale or distribution of a calendar that was printed which showed Jammu \& Kashmir as part of Afghanistan. File no 10 72/66 GO MS No 1089. Retrieved from the archives in April 2015.

Information Department. (1966, June 2). In response to a letter dated 20-666, Subject: Aid to newspapers. Letter no ID 72/66 Undersecretary to Government of India R K Govil on government policy of not giving any financial assistance. But the Enquiry Committee on Small Newspapers recommends financial assistance be given through state governments. Circulation to target intelligentsia in the state. Retrieved from the archives in April 2015.

Information Department. (1966, June 2). Letter no ID 17/10/66 Letter from GoI's Ministry of Information and Broadcasting to Secretary to Government of J\&K, Information Department, Government of Jammu and Kashmir, Srinagar. Printing presses will be property of government presses. Subsidies for three years along with industrial loans for four newspapers. Publication of a story has its own importance. Retrieved from the archives in April 2015.

Information Department. (1967, December 11). Government Order no IS97-A/1967. Weekly newspaper Our Country was prohibited from publication for three months by the Government of Jammu \& Kashmir under Chief Minister G. N. Sadiq for securing maintenance of public order, under 46 (1)b Defence of India Rules, 1962. Retrieved from the archives in April 2015.

Instrument of Accession. (1947). A copy of this document is in possession of the researcher.

Joseph, T. (2000). Kashmir, Human Rights and the Indian Press. Contemporary South Asia 9(1), pp. 41-55.

Kabir, A. (2009). Territory of Desire: Representing the Valley of Kashmir. Ranikhet: Permanent Black Publishers.

Kannabiran K., Singh N., Goswami R. \&Philipose P. (2020, March 4). Interrogating the "Normal" in Kashmir. Indian Cultural Forum. URL https://indianculturalforum.in/2020/03/04/interrogating-thenormal-in-kashmir/ Retrieved 19-04-2020. 
Mbembe, A. (2001). On the Postcolony. Berkeley: University of California Press.

Mughees-Uddin, S. (1992, October). Foreign Policy and Press Performance: The Case of the Kashmir Conflict, the United States and the New York Times during 1948-49 and 1989-91. Pakistan Horizon, 45(4). Pakistan Institute of International Affairs. URL: http:/ / www.jstor.org/stable/41393396 Retrieved: 3-4-2016.

Press Information Bureau. (1950, December 12). A complaint letter to Director General, Information, Jammu, J. N. Zutshi from Information and Broadcasting Ministry employee Mohammed Yusuf, about irregularities in the Counter Propaganda Department. Retrieved from the archives in April 2015.

Press Information Bureau (1964, November 11). Letter to Chief Secretary, Jammu and Kashmir (Jammu Tawi) E. Mangat Rai from Principal Information Officer L R Nair, Press Information Bureau, New Delhi, Government of India. Enclosed a note on recent issues of the Front, the Mahaz and the Azaan - all Srinagar weeklies - to give an idea on the type of material appearing in these papers. Some of these represent local political parties. Perhaps some positive results could be achieved by establishing contacts with these papers at public relations level. Simultaneously, the nationalist press in the state may also be encouraged to write more frequently with conviction and vigour in support of the Indian stand on Kashmir. We can even afford to be repetitive. A large flow of publicity material on development projects in the state will also be helpful in countering the negative policy of anti- India forces there. The PIB will be willing to supplement the efforts of the Directorate of Information on all-India scale. Retrieved from the archives in April 2015.

Press Information Bureau. (1964a, April 27). D/0 No NF/252-63-64. Letter from Minister for Information G M Sadiq to 10 editors and correspondents. We are aware of the usefulness of close contact between the Press and the Government. We are conscious of the help and cooperation we have been receiving from you at all stages. Retrieved from the archives in April 2015.

Press Information Bureau. (1965, November 11, 19, 23). List of critics of state practices and policies in each publication, both local and foreign. Retrieved from the archives in April 2015.

Raghunath, N. (2006). Jammu and Kashmir: Competing Concepts of Nationalism. Yale Journal of International Affairs, 2(1), 44-53 URL http:/ / yalejournal.org/pastissues_post/volume-2-issue-1-fallwinter2006/ Retrieved 27-4-2020. 
Rai, M. (2004). Islam, Rights, and the History of Kashmir: Hindu Rulers, Muslim Subjects. Ranikhet: Permanent Black.

Rasool, S. (2020, April 24). Kashmir and Press Freedom Ground Report from Kashmir. Counter Currents. URL https:// countercurrents.org/ 2020/04/kashmir-and-press-freedom Retrieved 26-04-2020.

Reddy, G. (2006, Apr.-June). Media and Public Policy. Indian Political Science Association, 67(2), 295-302. URL http:// www.jstor.org/ stable/ 41856216 Retrieved: 21-10- 2014.

Reporters Sans Frontiers (2020). World Press Freedom. Reporters without BordersIndex URL https://rsf.org/en/ranking Retrieved 27-04-2020.

Saikumar, R. (2019, August 6). Jammu and Kashmir: an integration without integrity. Thehindu.com URL https:// www.thehindu.com/ opinion/op-ed/an-integration-without-integrity/article28827038.ece

Scroll Staff. (2019, March 10). Kashmir newspapers publish blank front pages to protest government's ban on ads to two dailies. Scroll.in URL https:/ / scroll.in/latest/916038/kashmir-newspapers-publish-blankfront-pages-to-protest-governments-ban-on-ads-to-two-dailies Retrieved 19-04-2020.

Snedden, C. (2015). Understanding Kashmir and Kashmiris. London: C. Hurst \& Co. Ltd.

Sreedharan, C. (2009). Reporting Kashmir: An Analysis of the Conflict Coverage in Indian and Pakistani newspapers, $\mathrm{PhD}$ thesis, Bournemouth University.

Zia, A. (2019). Resisting disappearance: Military occupation and women's activism in Kashmir. Washington: University of Washington Press. 